\title{
Early-season predation on aphids by winter-active spiders in apple orchards revealed by diagnostic PCR
}

\author{
C. Boreau de Roincé ${ }^{1,2,3}$, C. Lavigne ${ }^{2}$, J.-F. Mandrin ${ }^{1}$, \\ C. Rollard ${ }^{4}$ and W.O.C. Symondson ${ }^{3 *}$
}

${ }^{1}$ Centre Technique Interprofessionnel des Fruits et Légumes, Centre de Balandran, BP 32, 30127 Bellegarde, France: ${ }^{2}$ INRA, UR 1115, Plantes et Systèmes de culture Horticoles, F-84000, Avignon, France: ${ }^{3}$ Cardiff School of Biosciences, Cardiff University, Sir Martin Evans Building, Museum Avenue, Cardiff CF10 3AX, UK: ${ }^{4}$ Muséum national d'Histoire naturelle, Département Systématique \& Evolution, USM OSEB, 61 rue Buffon, CP 53, 75005 Paris, France

\begin{abstract}
Aphids are major pests in apple orchards, debilitating the crop and spreading disease. We investigated whether early-season predation by canopy spiders may be effectively controlling aphid numbers in three organic orchards. For this purpose, we monitored the aphid population dynamics from the winter eggs to colony stages and compared this to spider abundances and rates of predation on aphids detected by diagnostic polymerase chain reaction. For the latter, we applied existing general aphid primers. We found that spiders ate colony fundatrices and that aphid numbers were negatively related to spider abundance. Spiders were the main active predators within the orchards when the first colony fundatrices were present, indicating their importance in the early control of aphid populations.
\end{abstract}

Keywords: Aphis pomi, conservation biological control, diagnostic PCR, Dysaphis plantaginea, generalist predator, gut content analysis

(Accepted 30 July 2012; First published online 2 November 2012)

\section{Introduction}

In European apple orchards, the rosy apple aphid Dysaphis plantaginea (Passerini), the green apple aphid Aphis pomi (de Geer) and the woolly apple aphid Eriosoma lanigerum (Hausmann) are considered to be the three main aphid pests of economic importance (Marc \& Canard, 1997). In particular, D. plantaginea can be the most detrimental, causing yield reductions from 30\% (Deberardinis et al., 1994; Blommers et al., 2004) to $80 \%$ (Qubbaj et al., 2005). Moreover, several other aphid species attack the apple trees, such as Aphis spiraecola

${ }^{*}$ Author for correspondence

Fax: + $44(0) 2920874116$

E-mail: Symondson@cardiff.ac.uk
(Pagenstecher), Rhopalosiphum insertum (Walker), Myzus varians (Davidson) and Myzus ornatus (Laing). Only A. pomi has the apple tree Malus domestica (Borkh) (Rosales: Rosaceae) as a unique host, but E. lanigerum and $A$. spiraecola are also permanently present on apple trees because they are anholocyclic in Europe (no sexual reproduction). The other species include the apple tree in their life cycle as a primary host in spring. Their alate migrants lay eggs in autumn, close to apple shoots, and start to hatch in late March. The migration of $D$. plantaginea winged adults to their secondary host, the plantain herb Plantago spp. (Lamiales: Plantaginaceae), begins in May and lasts until the end of June (Bonnemaison, 1959; Carroll \& Hoyt, 1984). Due to the exponential growth rate of these aphids, and their high damage risk, insecticide control is usually initiated at very low population levels. For example, insecticide treatment is recommended when a single 
D. plantaginea fundatrix is observed on a sample of 100 shoots (Minarro et al., 2005).

The need to control these aphids by non-chemical methods has stimulated research into the potential of natural enemies to suppress these pests in apple orchards (Carroll \& Hoyt, 1984; Mueller et al., 1988; Brown, 2004; Minarro et al., 2005; Fréchette et al., 2008; Dib et al., 2010). Two phases of control, involving different groups of predators, can be distinguished. Early in the season, before the aphid colonies build-up, biological control of aphids requires resident and actively foraging predators that are efficient at finding aphids even at very low density. These predators can have low predation rates because of the large impact that removal of small numbers of individuals can have on subsequent prey densities (Murdoch et al., 1985; Chang \& Kareiva, 1999). At that time, the main natural enemies are usually generalist predators because they are able to remain present in absence of a target pest, sustained on alternative prey (Symondson et al., 2002). After colonies have established and the exponential growth phase has begun, biological control of aphids requires more specialised natural enemies that have a high predation rate and/or growth rate, and are actively searching for colonies (Murdoch et al., 1985).

Among generalist predators of aphids, spiders possess characteristics that make them well-adapted for control of aphids early in the year. They are present on the canopy at the right time (Pekar \& Kocourek, 2004; Simon et al., 2009), and some species actively hunt in winter (Marc \& Canard, 1997; Miliczky et al., 2008; Korenko \& Pekar, 2010). In many instances, spiders kill more prey than they consume (Riechert \& Lockley, 1984; Greenstone, 1999). Wyss et al. (1995), looking at aphid remains in spider webs, found that web-building spiders contribute to the biological control of the D. plantaginea alate migrants in autumn. However, other studies, looking at communities of aphid predators (Brown, 2004; Minarro et al., 2005; Dib et al., 2010), concluded that spiders should not be considered as biocontrol agents of aphids because of their low abundance and predation rates compared to other groups, such as earwigs, ladybirds, syrphid and cecidomyiid flies, lacewings and true bugs. As these studies were looking at predation on well-established aphid colonies, their conclusions neglected the potential impact of spiders during the early phase of colony establishment.

Here, we hypothesised that spiders are significant predators that contribute to the early-season control of aphid pests in apple orchards. Two supplementary hypotheses were tested in support of this primary question: (i) early-season spiders eat aphid fundatrices, (ii) later appearance of colonies is negatively correlated with spider abundance early in the season. Other more specialised natural enemies (e.g. parasitoids) arrive when colonies are already established and growing exponentially, but any delay to the onset of this growth phase will improve the ability of these specialists to limit aphid population growth (Murdoch et al., 1985; Chiverton, 1986). To address this question of early season predation, the numbers of aphids and canopy-dwelling spiders were followed from mid-March until the end of April in three organic orchards. Predation on aphids by spiders was studied by gut content analyses with diagnostic polymerase chain reaction (PCR) using aphid-specific primers. Gut content analysis of predation by spiders on aphids has been widely used in cereal crops (see references in Harwood \& Obrycki, 2005; Kuusk et al., 2008). This has been shown to be an effective method for analysing predation by fluid-feeders in the field without disrupting the system under study (Greenstone, 1999; Symondson, 2002; King et al., 2008).

\section{Materials and methods}

Evaluation of the aphid specific primers

The aphid primers (Aphid F/Aphid R), originally designed by Chen et al. (2000) for detection of predation on cereal aphids, were tested for their ability to amplify DNA from the apple aphids D. plantaginea, A. pomi, A. spiraecola and E. lanigerum and the stonefruit aphids Myzus cerasi (Fabricius), Myzus persicae (Sulzer) and M. varians all collected locally. PCR was carried out in $10 \mu \mathrm{l}$ volume reactions using $1 \mu \mathrm{l}$ DNA template and the PCR protocol was adapted from Chen et al. (2000). PCR reactions contained $10 \mathrm{mM}$ Tris- $\mathrm{HCl}, \mathrm{pH} 9.0$, $1.5 \mathrm{mM} \mathrm{MgCl} 2,1.0 \mu \mathrm{M}$ of each primer, $50 \mathrm{mM} \mathrm{KCl}, 0.1 \mathrm{mM}$ of each dNTP, $0.05 \mathrm{U}^{-1} \mathrm{l}^{-1}$ of Taq DNA polymerase (Promega) and were performed in a PTC-200 thermocycler (MJ Research, Watertown, MA, USA). After an initial denaturing step of $3 \mathrm{~min}$ at $94^{\circ} \mathrm{C}$, a cycle of $94^{\circ} \mathrm{C}$ for $30 \mathrm{~s}, 52^{\circ} \mathrm{C}$ for $30 \mathrm{~s}$ and $72^{\circ} \mathrm{C}$ for $1 \mathrm{~min}$, was repeated 34 times, and then a last extension period at $72^{\circ} \mathrm{C}$ for $2 \mathrm{~min}$ was performed. PCR products were separated by electrophoresis in a $1.5 \%$ agarose gel with TBE buffer and visualised by ethidium bromide staining and photographed under UV light.

\section{Spider collection and aphid monitoring}

The three organic apple orchards were situated within a $5-\mathrm{km}^{2}$ area near Avignon in south-eastern France. In early March 2010, shoots, on which at least one aphid egg was observed, were marked with coloured plastic strips. For statistical independence, each marked shoot was on a different tree. Respectively, 17, 14 and 30 shoots were marked in orchards 1, 2 and 3. To collect spiders within all canopy habitats, two cardboard traps (10-cm wide bands, secured with elastic bands) that mimic tree bark were installed on each sampled tree, one wrapped around the branch next to the marked shoot and the other around the main trunk ( $1 \mathrm{~m}$ above the ground). This trapping method is considered the best technique to sample spiders that use tree bark as a shelter (Mizell \& Schiffhauer, 1987), as well as webbuilding spiders when the foliage is absent (Marc \& Canard, 1997). The shoot was considered the sampling unit for aphid numbers and the two cardboard traps the sampling unit for the spider community. The marked shoots were observed weekly for fundatrices and the presence of colonies on six occasions in early spring (22 and 31 March; 7, 14, 22 and 27 April). On 6 May, trees corresponding to the marked shoots were carefully examined, and the number of colonies and aphids per colonies were assessed. As D. plantaginea is easy to recognize by its grey colouration, we distinguished the $D$. plantaginea colonies from the other green aphid colonies ( $A$. pomi, $R$. insertum, A. spiraecola, $M$. varians, $M$. ornatus) which cannot be separated to species in the field. Spiders were collected at the same time as the aphid monitoring except on the last date (27 April) for all orchards and on 22 March in orchard 2. In order to avoid local population depletion in orchard 3, where trees were young, spiders were retrieved in trees marked even (15 trees) one week and in trees marked odd (15 trees) the following week. At each sampling time, the cardboard traps were unwrapped 
a) Orchard 1

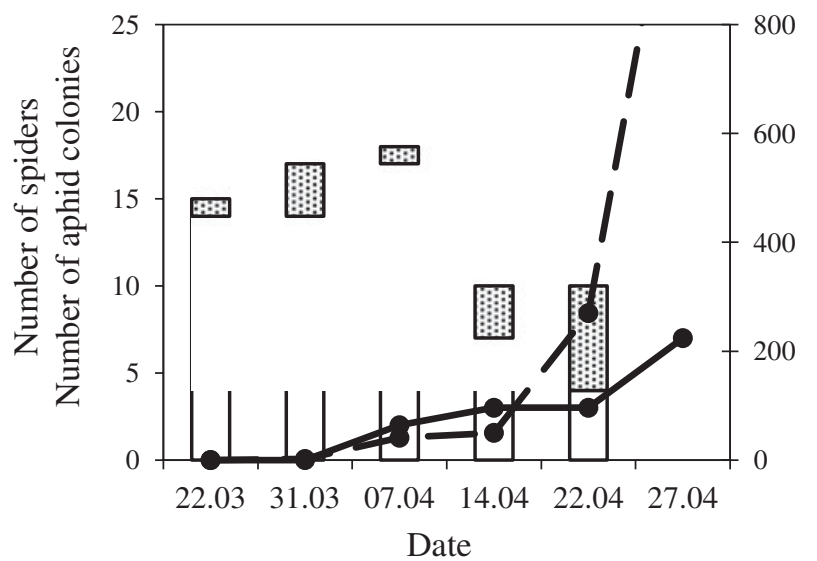

b) Orchard 2

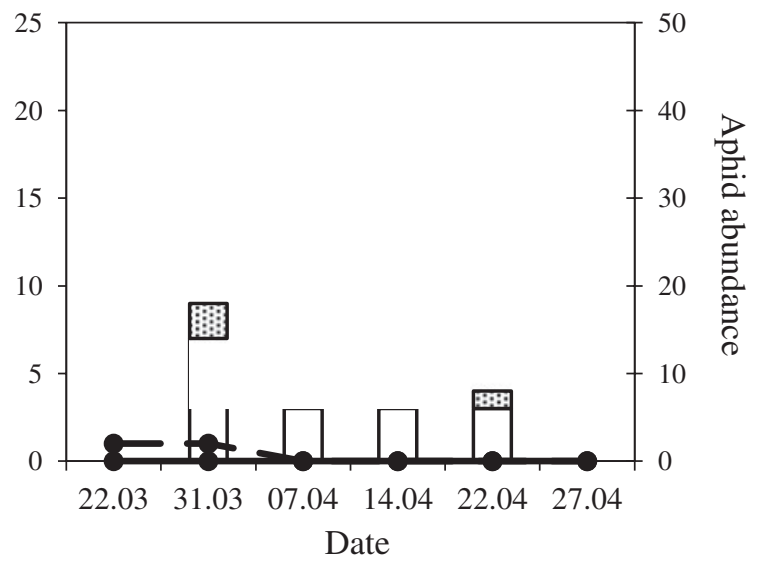

c) Orchard 3

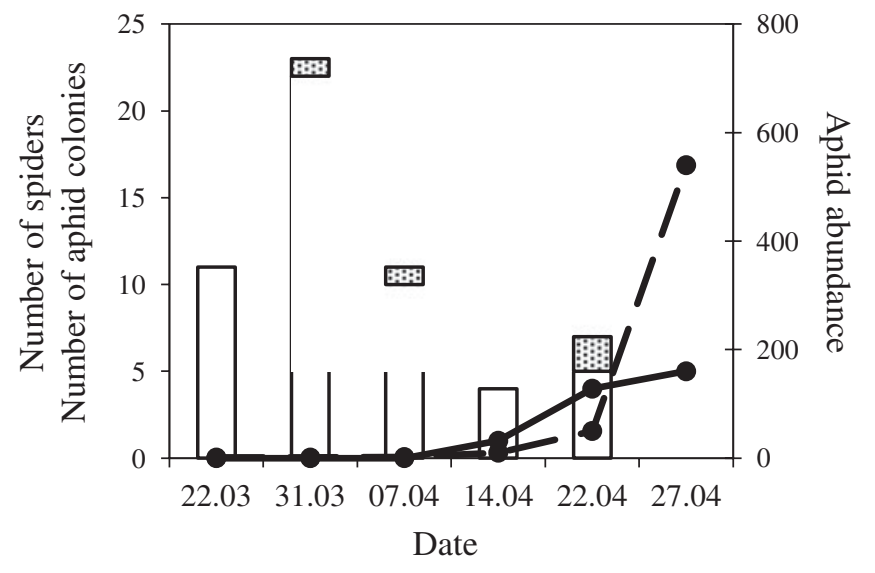

Fig. 1. Numbers of spiders (bars, Y1-axis), aphid colonies (black line, Y1-axis) and aphids (dashed line, Y2-axis) in three apple orchards (a) orchard 1, (b) orchard 2 and (c) orchard 3. Spiders detected positive by the aphid-specific diagnostic PCR are represented by the shading on the bars.

from the tree and allowed to fall into a $4 \mathrm{~cm} \times 25 \mathrm{~cm}$ tray. Predators were shaken out and the same trap secured again in the tree. In addition to spiders, small numbers of overwintering tenebrionids, ladybirds and earwigs were found, but as they are inactive at this time, they were not sampled or tested for predation on aphids. Spiders were collected individually into Eppendorf tubes then stored in a cool box $\left(4^{\circ} \mathrm{C}\right)$ for a maximum of $3 \mathrm{~h}$ and frozen at $-20^{\circ} \mathrm{C}$ in the laboratory. They were identified before DNA extraction. Identification was to genus level only for species for which juveniles cannot be determined to species. The DNA was extracted with the Qiagen DNeasy ${ }^{8}$ Blood \& Tissue extraction kit, resuspended in $200 \mu \mathrm{l}$ of manufacturer's elution buffer and stored at $-20^{\circ} \mathrm{C}$. Finally, extraction success was verified by amplification of the spider DNA with the universal arthropod primers LCO1490 and HCO2198 (Folmer et al., 1994), and any possibility of crossover contamination within batches of samples was excluded by the use of negative controls (water) (King et al., 2008).

\section{Data analysis}

Factors influencing aphid predation by spiders

The effects of orchard, spider identity (species or genus level), canopy habitat (branch or trunk), aphid population (number of aphids per shoot) and date were tested against the probability of detecting aphid DNA in the spider guts, using a general linear model with binomial family errors and logit link function (R Development Core Team, 2011).

\section{Effect of spiders on the emergence of aphid colonies}

The binary variable "presence or absence of aphid colonies on the shoot on 22 April" was set up from the aphid records. The abundances of spiders collected from 22 March to 22 April in the corresponding tree were summed. And so, the number of aphid-positive spiders was calculated as the sum of all positive spiders for aphid predation collected from 22 March to 22 April in the corresponding tree. The effects of orchard, spider abundance and number of aphid-positive spiders on 
Table 1. Composition of the spider assemblage and their predation on aphids detected by the aphid-specific diagnostic PCR in three orchards.

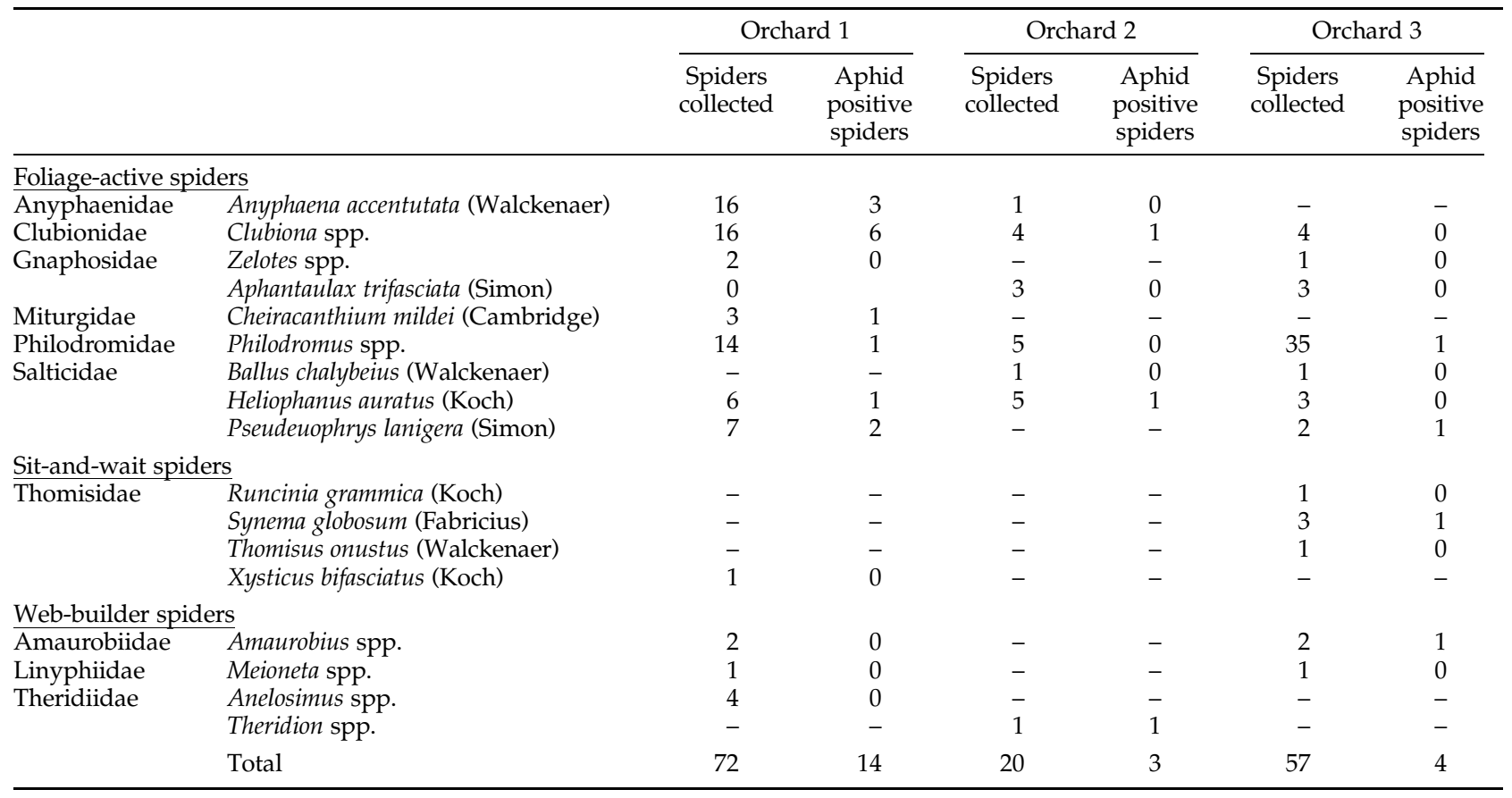

the presence/absence of aphid colonies were tested using a generalised linear model with binomial family errors and logit link function.

\section{Results \\ Amplification of orchard aphid DNA}

The general aphid primers only failed to amplify the DNA from E. lanigerum, which was not observed in the orchards.

\section{Aphid dynamics}

The mean initial number of eggs per shoot was $1.3 \pm 0.1$ (mean $\pm \mathrm{SE}$ ), $1.0 \pm 0.0$ and $1.3 \pm 0.2$ in orchards 1,2 and 3, respectively, and was not different between orchards (Kruskal-Wallis $\chi^{2}=3.639, \mathrm{df}=2, P=0.162$ ). The first fundatrices were recorded on $22 \mathrm{March}$ and the first $D$. plantaginea colony was observed on 22 April, two weeks after the first appearance of other aphid colonies (7 April). Dysaphis plantaginea colonies represented $23.5 \%$ of the total number of colonies on 27 April (ten colonies) and $71 \%$ of the total number of colonies on 6 May (27 colonies). At the end of shoot monitoring (27 April), $23.6 \%$ of the marked shoots (i.e. for which at least one aphid egg was initially observed) were infested by an aphid colony in orchard 1, 13.3\% in orchard 3 and none in orchard 2. On 27 April, the aphid population was at the beginning of its exponential growth phase (fig. 1).

\section{Spider communities and other predators}

In total, 149 spiders were collected in the three orchards (72, 20 and 57 in orchards 1, 2 and 3, respectively) (table 1). The mean numbers of spiders collected per tree and sampling occasion were, respectively, $0.85 \pm 0.09,0.34 \pm 0.09$ and $0.71 \pm 0.22($ mean $\pm S E)$ in orchards 1,2 and 3 and were significantly different between orchards (Kruskal-Wallis $\chi^{2}=6.379, \mathrm{df}=2, P=0.041$ ). The spider communities differed between orchards. Orchard 1 and orchard 3 displayed speciesrich communities; orchard 3 was dominated by Philodromus spp.; and orchard 2, particularly, lacked web-building and sitand-wait spiders (table 1).

\section{Predation by spiders on aphids}

Spiders were found positive for aphid consumption from 22 March, which was two weeks before the first observation of colonies (fig. 1). In consequence, from 22 March to 7 April, it is likely that spiders attacked colony fundatrices. The probability of detecting aphid DNA in the spider guts increased with the number of aphids per shoot $(\mathrm{F}=7.52, \mathrm{df}=1, P=0.007)$ and depended on the date $(\mathrm{F}=4.00, \mathrm{df}=4, P=0.004)$ but was not explained by spider identity $(\mathrm{F}=1.37, \mathrm{df}=20, P=0.15)$, orchard $(\mathrm{F}=2.40, \mathrm{df}=2, P=0.09)$ and canopy habitat, i.e. branch or trunk, $(\mathrm{F}=0.16, \mathrm{df}=1, P=0.69)$. Temperature thresholds for most other potential natural enemies of aphids make it unlikely that these were active at this time (none were observed).

\section{Effect of spiders on the presence of colonies}

The presence of aphid colonies on 22 April was related to spider abundance $(\mathrm{F}=6.035, \mathrm{df}=1, P=0.017)$, number of aphid-positive spiders $(\mathrm{F}=10.023, \mathrm{df}=1, P=0.003)$ and orchard $(\mathrm{F}=3.167, \mathrm{df}=2, P=0.049)$ (fig. 1). The relationship was negative (parameter estimation $=-1.134$ ) for spider abundance only, showing that shoots from trees with more spiders were 
less likely to harbour an aphid colony. The presence of aphid colonies was positively related (parameter estimation $=2.321$ ) to the number of aphid-positive spiders, suggesting density dependent predation on aphids.

\section{Discussion}

The impact of the early-season predation by spiders on aphid populations was studied by analysing earlyseason aphid population dynamics, spider abundances and predation rates on aphids. Gut content analyses revealed predation events on aphid fundatrices. Spider identity, and their location within the canopy, had no significant effect on predation rates, although numbers were low, and therefore this result should be treated with caution. Aphid abundance had a positive effect on predation rates. Moreover, the presence of an aphid colony on a shoot was negatively correlated with early-season spider abundance in the corresponding tree.

Previous studies hypothesized that spiders could play an important role in the control of pests during winter (Marc \& Canard, 1997; Marc et al., 1999; Korenko \& Pekar, 2010) because some spiders are able to remain active in winter and hunt for prey at low temperatures (Korenko et al., 2010). Indeed, our results clearly showed that spiders prey upon colony fundatrices. They also suggested that spiders were mobile within the canopy; as, within this limited sample of spiders, those collected on the trunk were equally positive for predation on aphids as spiders collected on the shoots where the eggs/fundatrices were present. Moreover, other potential predators of aphids were unlikely to have been active during March and early April, and activity was not observed. The temperature thresholds for development of $D$. plantaginea and A. pomi are $4.5^{\circ} \mathrm{C}$ and $5.9^{\circ} \mathrm{C}$, respectively (Graf et al., 1985), which means that predators must be active around this temperature threshold to prey upon fundatrices. Korenko et al. (2010) showed that Philodromus spp. and Anyphaenea accuentata (Walckenaer), which were present in their study orchard, had lower temperature thresholds of predatory activity than the developmental thresholds of $D$. plantaginea and $A$. pomi $\left(1.2^{\circ} \mathrm{C}\right.$ and $3.5^{\circ} \mathrm{C}$, respectively). In consequence, these winteractive spiders are above their temperature threshold of activity when the first $D$. plantaginea and $A$. pomi eggs hatch. By contrast, temperature thresholds for other predators on apple trees are higher than those for the aphids, with $6^{\circ} \mathrm{C}$ for the earwig Forficula auricularia (Helsen et al., 1998) and the hoverfly Episyrphus balteatus (Hart et al., 1997), $9.0^{\circ} \mathrm{C}$ for the ladybird Adalia bipunctata (Obrycki \& Tauber, 1981) and $10.5^{\circ} \mathrm{C}$ for the cecidomyiid fly Aphidoletes aphidimyza (Morse \& Croft, 1987). These predators were indeed reported to prey upon aphids later in the season when the first colonies are already established (Dib et al., 2010). Thus, temporal niche partitioning (Finke \& Snyder, 2010) for aphids as a prey resource results from this difference in phenology among predators, reducing predator interference and limiting temporal refugia for pests (Symondson et al., 2002). Nevertheless, spiders are known to be intraguild predators (Hodge, 1999; Wise, 2006), and their impact on other natural enemies should be studied before assuming niche complementarity between predators.

There are indicators suggesting that spiders may have been efficient at controlling aphid numbers in the present study. First, the time lag between the presence of the first fundatrices and their predation by predators is a critical factor for the appearance of colonies and their subsequent damage (Wyss et al., 1999; Brown, 2011). In particular, Brown (2011) concluded that limitation of $D$. plantaginea colony development is more efficient when predation occurs within the first week of colony establishment. Here, spiders tested positive for predation on aphids as soon as the first eggs hatched and were, thus, likely to have had a considerable impact on aphid population dynamics, for example delaying the aphid exponential growth phase (Birkhofer et al., 2008). Second, control of colony development is improved by high initial predator abundance (Wyss et al., 1999). Here, the presence of a colony was indeed negatively correlated to the initial spider abundance on a tree. Finally, although prey preferences (Agustí et al., 2003) and functional specialisation (Marc \& Canard, 1997) are common in spiders, this may not be the case in winter when prey are scarce (Marc et al., 1999). Spider identity was not significant in explaining predation on aphids, but more work would be needed with larger sample sizes to confirm this. Results so far indicate that no specific taxa would need to be particularly encouraged for early-season control of aphids.

To conclude, our results support the hypothesis that spiders are important for the early-season control of aphids. Furthermore, the impact of spiders on aphid populations delays the exponential growth phase and, therefore, increases the effectiveness of other predators (and parasitoids) that are active later in the season. The high potential of spiders as intraguild predators, and positive and negative effects of spiders within a predator assemblage (Hodge, 1999), needs further study if their role in aphid suppression within conservation biological control programmes is to be fully understood.

\section{Acknowledgements}

This work was funded by the Centre Technique Interprofessionnel des Fruits et Légumes. Catherine Boreau de Roincé's PhD was granted by a CIFRE from the Association Nationale de la Recherche et de la Technologie. We are thankful to Laetitia Durlin and Jean-Michel Ricard for their help with field work, and to the farmers, Jean-François Toubon and Jean-Charles Bouvier for coordination.

\section{References}

Agustí, N., Shayler, S.P., Harwood, J.D., Vaughan, I.P., Sunderland, K.D. \& Symondson, W.O.C. (2003) Collembola as alternative prey sustaining spiders in arable ecosystems: prey detection within predators using molecular markers. Molecular Ecology 12, 3467-3475.

Birkhofer, K., Gavish-Regev, E., Endlweber, K., Lubin, Y.D., von Berg, K., Wise, D.H. \& Scheu, S. (2008) Cursorial spiders retard initial aphid population growth at low densities in winter wheat. Bulletin of Entomological Research 98, 249-255.

Blommers, L.H.M., Helsen, H.H.M. \& Vaal, F. (2004) Life history data of the rosy apple aphid Dysaphis plantaginea (Pass.) (Homopt., Aphididae) on plantain and as migrant to apple. Journal of Pest Science 77, 155-163.

Bonnemaison, L. (1959) Le puceron cendré du pommier (Dysaphis plantaginea Pass.) Morphologie et biologie - Méthodes de lutte. Annales INRA, Série C Epiphyties III, 257-322. 
Brown, M.W. (2004) Role of aphid predator guild in controlling spirea aphid populations on apple in West Virginia, USA. Biological Control 29, 189-198.

Brown, M.W. (2011) Importance of early arrival of adult Harmonia axyridis for control of Aphis spiraecola on apple. Biocontrol 56, 65-69.

Carroll, D.P. \& Hoyt, S.C. (1984) Natural enemies and their effect on apple aphid, Aphis pomi Degeer (Homoptera, Aphididae), colonies on young apple trees in central Washington. Environmental Entomology 13, 469-481.

Chang, G.C. \& Kareiva, P. (1999) The case for indigenous generalists in biological control. pp. 103-115 in Hawkins, B. \& Cornell, H. (Eds) Theoretical Approaches to Biological Control. Cambridge, UK, Cambridge University Press.

Chen, Y., Giles, K.L., Payton, M.E. \& Greenstone, M.H. (2000) Identifying key cereal aphid predators by molecular gut analysis. Molecular Ecology 9, 1887-1898.

Chiverton, P.A. (1986) Predator density manipulation and its effects on populations of Rhopalosiphum padi (Hom, Aphididae) in spring barley. Annals of Applied Biology 109, 49-60.

Deberardinis, E., Baronio, P. \& Baumgartner, J. (1994) The effect of aphid (Dysaphis plantaginea Pass, Hom, Aphididae) feeding on apple fruit growth. Ecological Modelling 72, 115-127.

Dib, H., Simon, S., Sauphanor, B. \& Capowiez, Y. (2010) The role of natural enemies on the population dynamics of the rosy apple aphid, Dysaphis plantaginea Passerini (Hemiptera: Aphididae) in organic apple orchards in south-eastern France. Biological Control 55, 97-109.

Finke, D.L. \& Snyder, W.E. (2010) Conserving the benefits of predator biodiversity. Biological Conservation 143, 2260-2269.

Folmer, O., Black, M., Hoeh, W., Lutz, R. \& Vrijenhoek, R. (1994) DNA primers for amplification of mitochondrial cytochrome c oxidase subunit I from diverse metazoan invertebrates. Molecular Marine Biology and Biotechnology 3, 294-299.

Fréchette, B., Cormier, D., Chouinard, G., Vanoosthuyse, F. \& Lucas, E. (2008) Apple aphid, Aphis spp. (Hemiptera: Aphididae), and predator populations in an apple orchard at the non-bearing stage: The impact of ground cover and cultivar. European Journal of Entomology 105, 521-529.

Graf, B., Baumgärtner, J. \& Delucchi, V. (1985) Life table statistics of three apple aphids, Dysaphis plantaginea, Rhopalosiphum insertum, and Aphis pomi (Homoptera, Aphididae), at constant temperatures. Zeitschrift für Angewandte Entomologie 99, 285-294.

Greenstone, M.H. (1999) Spider predation: How and why we study it. Journal of Arachnology 27, 333-342.

Hart, A.J., Bale, J.S. \& Fenlon, J.S. (1997) Developmental threshold, day-degree requirements and voltinism of the aphid predator Episyrphus balteatus (Diptera: Syrphidae). Annals of Applied Biology 130, 427-437.

Harwood, J.D. \& Obrycki, J.J. (2005) Quantifying aphid predation rates of generalist predators in the field. European Journal of Entomology 102, 335-350.

Helsen, M., Vaal, F. \& Blommers, L. (1998) Phenology of the common earwig Forficula auricularia L. (Dermaptera: Forficulidae) in an apple orchard. International Journal of Pest Management 44, 75-79.

Hodge, M.A. (1999) The implications of intraguild predation for the role of spiders in biological control. Journal of Arachnology 27, 351-362.

King, R.A., Read, D.S., Traugott, M. \& Symondson, W.O.C. (2008) Molecular analysis of predation: a review of best practice for DNA-based approaches. Molecular Ecology 17, 947-963.
Korenko, S. \& Pekar, S. (2010) Is there intraguild predation between winter-active spiders (Araneae) on apple tree bark? Biological Control 54, 206-212.

Korenko, S., Pekar, S. \& Honek, A. (2010) Predation activity of two winter-active spiders (Araneae: Anyphaenidae, Philodromidae). Journal of Thermal Biology 35, 112-116.

Kuusk, A.K., Cassel-Lundhagen, A., Kvarnheden, A. \& Ekbom, B. (2008) Tracking aphid predation by lycosid spiders in spring-sown cereals using PCR-based gut-content analysis. Basic and Applied Ecology 9, 718-725.

Marc, P. \& Canard, A. (1997) Maintaining spider biodiversity in agroecosystems as a tool in pest control. Agriculture Ecosystems E Environment 62, 229-235.

Marc, P., Canard, A. \& Ysnel, F. (1999) Spiders (Araneae) useful for pest limitation and bioindication. Agriculture Ecosystems $\mathcal{E}$ Environment 74, 229-273.

Miliczky, E.R., Horton, D.R. \& Calkins, C.O. (2008) Observations on phenology and overwintering of spiders associated with apple and pear orchards in south-central Washington. Journal of Arachnology 36, 565-573.

Minarro, M., Hemptinne, J.L. \& Dapena, E. (2005) Colonization of apple orchards by predators of Dysaphis plantaginea: sequential arrival, response to prey abundance and consequences for biological control. Biocontrol 50, 403-414.

Mizell, R.F. \& Schiffhauer, D.E. (1987) Trunk traps and overwintering predators in pecan orchards: survey of species and emergence times. Florida Entomologist 70, 238-244.

Morse, J.G. \& Croft, B.A. (1987) Biological control of Aphis pomi Hom, Aphididae of Aphidoletes aphidimyza Dip, Cecidomyiidae: a predator-prey model. Entomophaga 32, 339-356.

Mueller, T.F., Blommers, L.H.M. \& Mols, P.J.M. (1988) Earwig (Forficula auricularia) predation on the woolly apple aphid, Eriosoma lanigerum. Entomologia Experimentalis et Applicata 47, 145-152.

Murdoch, W.W., Chesson, J. \& Chesson, P.L. (1985) Biological control in theory and practice. American Naturalist 125, 344-366.

Obrycki, J.J. \& Tauber, M.J. (1981) Phenology of three coccinellid species thermal requirements for development. Annals of the Entomological Society of America 74, 31-36.

Pekar, S. \& Kocourek, F. (2004) Spiders (Araneae) in the biological and integrated pest management of apple in the Czech Republic. Journal of Applied Entomology 128, 561-566.

Qubbaj, T., Reineke, A. \& Zebitz, C.P.W. (2005) Molecular interactions between rosy apple aphids, Dysaphis plantaginea, and resistant and susceptible cultivars of its primary host Malus domestica. Entomologia Experimentalis et Applicata 115, 145-152.

R Development Core Team (2011) R: A language and environment for statistical computing. R Foundation for Statistical Computing, Vienna, Austria. Available online at http:// www.R-project.org (accessed 20 September 2012).

Riechert, S.E. \& Lockley, T. (1984) Spiders as biological control agents. Annual Review of Entomology 29, 299-320.

Simon, S., Bouvier, J.C., Debras, J.F. \& Sauphanor, B. (2009) Biodiversity and pest management in orchard systems. A review. Agronomy for Sustainable Development 30, 139-152.

Symondson, W.O.C. (2002) Molecular identification of prey in predator diets. Molecular Ecology 11, 627-641. 
Symondson, W.O.C., Sunderland, K.D. \& Greenstone, M.H. (2002) Can generalist predators be effective biocontrol agents? Annual Review of Entomology 47, 561-594.

Wise, D.H. (2006) Cannibalism, food limitation, intraspecific competition and the regulation of spider populations. Annual Review of Entomology 51, 441-465.

Wyss, E., Niggli, U. \& Nentwig, W. (1995) The impacts of spiders on aphid populations in a strip-managed apple orchard.
Journal of Applied Entomology-Zeitschrift Fur Angewandte Entomologie 119, 473-478.

Wyss, E., Villiger, M., Hemptinne, J.L. \& Muller-Scharer, H. (1999) Effects of augmentative releases of eggs and larvae of the ladybird beetle, Adalia bipunctata, on the abundance of the rosy apple aphid, Dysaphis plantaginea, in organic apple orchards. Entomologia Experimentalis et Applicata 90, 167-173. 